\title{
Oceanographic and behavioural processes affecting invertebrate larval dispersal and supply in the western Iberia upwelling ecosystem
}

\author{
Henrique Queiroga ${ }^{\mathrm{a}, *}$, Teresa Cruz ${ }^{\mathrm{b}}$, Antonina dos Santos ${ }^{\mathrm{c}}$, Jesus Dubert ${ }^{\mathrm{d}}$, \\ Juan Ignácio González-Gordillo e , José Paula ${ }^{\mathrm{f}}$, Álvaro Peliz ${ }^{\mathrm{d}}$, \\ A. Miguel P. Santos ${ }^{\text {c }}$ \\ a Departamento de Biologia, CESAM - Centro de Estudos do Ambiente e do Mar, Universidade de Aveiro, 3810-193 Aveiro, Portugal \\ b Laboratório de Ciências do Mar, Universidade de Évora, 7520-903 Sines, Portugal \\ ${ }^{\mathrm{c}}$ Instituto Nacional de Investigação Agrária e das Pescas - IPIMAR, Av. Brasília, s/n, 1449-006 Lisboa, Portugal \\ d Departamento de Física, CESAM - Centro de Estudos do Ambiente e do Mar, Universidade de Aveiro, 3810-193 Aveiro, Portugal \\ e Centro Andaluz de Ciencia y Tecnología Marina, Campus de Puerto Real, Universidad de Cádiz, E-11510 Puerto Real (Cádiz), Spain \\ ${ }^{\mathrm{f}}$ IMAR - Laboratório Marítimo da Guia, Departamento de Biologia Animal, Faculdade de Ciências da Universidade de Lisboa, \\ Estrada do Guincho, 2750-374 Cascais, Portugal
}

Available online 19 April 2007

\begin{abstract}
The present review addresses recent findings made in the western Iberia ecosystem on the behavioural and physical interactions that regulate dispersal, supply to coastal habitats and settlement of invertebrate larvae. These studies used the barnacle Chthamalus spp. and the crab Carcinus maenas as model organisms. The observations made on the Iberian shelf showed extensive diel vertical migrations along the water column by representatives of both groups that have never been reported before. The interaction of the diel vertical migration with the two-layer flow structure of upwelling/downwelling circulation suggests a mechanism that may help to retain larvae in shelf waters during upwelling conditions. Measurements of daily supply of $C$. maenas megalopae to estuaries separated by $500 \mathrm{~km}$ disclosed a semilunar pattern, with highest supply around highest amplitude tides, indicating that supply of megalopae to estuaries is accomplished by selective tidal stream transport. Relaxation of equatorward winds also played a role in supply, by enhancing translocation of megalopae to the nearshore. Concerning Chthamalus larvae, the observations on daily settlement made at rocky shores also separated by $500 \mathrm{~km}$ showed unclear patterns between locations and years. The relationship of settlement with water temperature, tidal range and upwelling indices indicated that supply of barnacle cyprids may be controlled by multiple mechanisms, viz. upwelling/downwelling circulation, internal tidal bores and sea breezes.
\end{abstract}

(C) 2007 Elsevier Ltd. All rights reserved.

Keywords: Invertebrates; Larvae; Recruitment; Dispersal; Upwelling; Tides; Vertical migration; Behaviour; Western Iberia

\footnotetext{
* Corresponding author. Tel.: +351 234370787; fax: +351 234426408.

E-mail address: hqueiroga@bio.ua.pt (H. Queiroga).
} 


\section{Introduction}

Barnacles and crabs are two of the most charismatic invertebrates of littoral ecosystems. Species of both groups form large populations of adults in rocky shores and in estuaries that have the capacity to strongly affect the community structure through spatial interference competition in the case of barnacles (Hughes and Griffiths, 1988; Wootton, 1993), and through predation in the case of crabs (Virnstein, 1977). Recognition of these phenomena, as well as the high economic value of several crab species, has led researchers to investigate the factors that control recruitment of these species in coastal communities, looking either to processes that regulate dispersal and supply of larvae before settlement and to factors that affect post-settlement growth and mortality (Connell, 1985; Underwood and Fairweather, 1989). Research of these processes is helped by the great numbers that larval, juvenile and adult populations reach and by the fact that these invertebrate groups have conspicuous larvae that are relatively easy to identify from plankton or benthos samples and to rear in the laboratory.

Recruitment may be broadly defined as the replenishment of a population with new individuals due to the processes of reproduction and growth. For marine species with indirect development, recruitment involves several steps: larval development, dispersal during development, supply to appropriate settlement habitats, settlement, and juvenile development. The present paper reviews recent findings of processes that affect dispersal, supply and settlement of larvae of barnacles of the genus Chthamalus and of the portunid crab Carcinus maenas to rocky shores and estuaries on the west coast of Iberia. This review is focused on the mechanisms of acrossshelf translocation and supply to coastal habitats. Therefore, processes from hatching to accumulation in the larval pool (sensu Pineda, 2000) and post-settlement processes are not considered here. Dispersal, supply and settlement depend on several processes that regulate larval production and availability, as well as on interactions between larval behavioural traits and different components of the coastal ocean circulation. These are complex problems and marine biologists are still far from having a comprehensive knowledge of how they act individually and collectively for any single species or group. Extensive information on the larval ecology of C. maenas has been produced during recent years, including hatching periodicity (Queiroga et al., 1994; Zeng and Naylor, 1997), synchronisation of vertical migration with the tidal cycle (Zeng and Naylor, 1996a,b,c), influence of tidally synchronised migrations on export and reinvasion of estuaries (Queiroga et al., 1997; Queiroga, 1998), and offshore distribution of larval stages (Queiroga, 1996). Several studies have addressed the biology of C. stellatus and Chthamalus montagui in European coasts, namely reproductive period (Burrows et al., 1992; O’Riordan et al., 1992, 1995), larval development time (Burrows et al., 1999), settlement (Cruz, 1999; O'Riordan et al., 2004; Cruz et al., 2005) and adult distribution patterns (Sousa et al., 2000; Range and Paula, 2001; Boaventura et al., 2002). A wealth of information is available on factors that affect growth rates, feeding and mortality in invertebrate larvae. Most of these factors were investigated in laboratory conditions and, despite several difficulties in translating process rates to the natural environment, this information is essential to understand the larval ecology of marine organisms. The interested reader in these factors is addressed to the reviews of Anger (2001), Boidron-Métairon (1995) and Morgan (1995). Some efforts have been made to track the path of patches of larvae from hatching to settlement, but these have been mostly confined to brachyuran crabs and have not been able to follow the complete chain of events during the several weeks of development in the plankton (Natunewicz and Epifanio, 2001; Natunewicz et al., 2001; Petrone et al., 2005).

Most of the information described in the present paper on patterns of distribution in shelf waters, and of supply of crab and barnacle larvae to coastal habitats, is based on results obtained within the ProRecruit Project, which have been published recently as contributions to the GLOBEC programme (Cruz, 2003; dos Santos et al., 2007, submitted for publication; Marta-Almeida et al., 2006; Queiroga et al., 2006; Peliz et al., 2006). Different aspects of the oceanographic circulation in Iberia are described in this volume (Relvas et al., 2007). We will give a brief synopsis in the cases where they have been implicated in dispersal and transport, highlighting the bio-physical interactions involved in each case. We will then describe the general hypotheses addressed by these studies. Two sections are dedicated to the main findings related to patterns of recruitment to littoral populations and to the vertical distribution in shelf waters. Finally, we will emphasize the general importance of the main findings.

The data reviewed in this paper bring new insights into our understanding of the interactions between larval biology and physical forcing that are involved in dispersal, supply and recruitment to coastal populations of 
barnacles and crabs. Our observations show that crab and barnacle larvae may perform extensive diel vertical migrations along the water column that have not been described before. Interaction of diel vertical migrations with upwelling/downwelling circulation suggests a general mechanism for retention of larvae in shelf waters of upwelling systems. Observed patterns of supply of crab megalopae to estuaries indicate that relaxation of upwelling results in onshore translocation of megalopae, and that selective tidal stream transport is involved in the final step of supply to estuaries. Concerning barnacle larvae, the observations on settlement show unclear patterns indicating a combination of multiple mechanisms controlling supply to coastal habitats.

\section{Bio-physical interactions that regulate supply of invertebrate larvae to coastal habitats}

\subsection{Across-shelf transport}

Winds, tides and frontal structures have been recognised as amongst the most important physical processes accounting for the shoreward movement of larvae of coastal invertebrates and fish. These processes have been reviewed by several authors (Boehlert and Mundy, 1988; Shanks, 1995; Pineda, 2000; Queiroga and Blanton, 2005). A brief synopsis is given here where they are thought to be relevant for the interpretation and significance of the observations made in the Iberian Peninsula.

Wind-driven circulation has been identified in the shoreward transport of dinoflagellates (Fraga et al., 1988) as well as barnacle (Roughgarden et al., 1988; Farrell et al., 1991; Roughgarden et al., 1991) and crab (Almeida and Queiroga, 2003) larvae in eastern boundaries of the North Pacific and the North Atlantic. These studies detected increased concentrations in the near-shore or increased settlement rates following relaxation of equatorward winds, which have been interpreted as resulting from the coastal convergence of the surface Ekman layer, or of the upwelling front, during these periods. Furthermore, aggregation of invertebrate larvae at an upwelling front propagating towards shore during relaxation of upwelling-favourable winds has also been demonstrated (Shanks et al., 2000). Spatial variation in larval supply at local and regional scales has been related to spatial patterns of upwelling and with its interaction with coastal features. One example are the differences in supply levels associated with latitudinal differences in upwelling strength along the coast (Connolly et al., 2001). Another example occurs when eddies trapped at the leeward side of promontories during upwelling are released after relaxation of the winds, with a subsequent poleward alongshore flow redistributing the larvae in the region (Wing et al., 1995a). Studies on the influence of upwelling circulation on cross-shelf transport of larvae have been conducted by correlating measures of supply or settlement at several points along the coast with strength of along-shore winds and water temperature and salinity. These studies have typically found high rates of supply or settlement following relaxation of the equatorward winds and concurrently with arrival of warm water at the coast, which replaces the cooler and denser upwelled water.

The generalization allowed by the studies reviewed in the former paragraph is that supply of larvae to coastal habitats increases or decreases with the intensification or relaxation of upwelling, respectively. However, some recent observations on gastropod and bivalve veligers, which are relatively slow swimmers, indicate a role of larval behaviour in the control of across-shelf dispersal. Competent veligers of the gastropod Concholepas concholepas perform reversed diel vertical migrations occupying the neuston layer during the day. This behaviour apparently takes them to depths below the thermocline into the shoreward compensating undercurrent during the night, resulting in increasing concentrations shoreward of the upwelling front during upwelling events (Poulin et al., 2002a,b). A different mechanism is exhibited by the veligers of the bivalves Tellina spp. and Mulinia lateralis. Larvae of these species released from coastal habitats swim against the slow vertical currents produced during upwelling and downwelling. This swimming behaviour prevents the larvae from being carried seaward in the surface or bottom layers during upwelling or downwelling events respectively, effectively avoiding offshore dispersal (Shanks and Brink, 2005). Therefore, the implicit interpretation of former studies that upwelling does necessarily lead to offshore dispersal and wastage from coastal habitats may not hold true in many cases.

Other mechanisms of advection of larvae in response to wind events have also been described. Wind episodes with return periods of weeks to months, such as the passage of cold fronts and hurricanes, may result in storm surges and in the increase of subtidal sea level at the coast. These phenomena have been implicated in the increased supply of crab megalopae to estuarine systems (Goodrich et al., 1989). If larvae remain in the 
neuston layer then they may be transported down-wind. This is the mechanism suggested to explain correlations between onshore wind velocity and settlement of barnacle cyprids (Hawkins and Hartnoll, 1982). Sea breezes, which have a periodic nature, have also been proposed to transport neustonic larvae down-wind (Shanks, 1995). However, there are no observations to clearly support this process, and a recent study failed to predict trajectories of surface drifters from measurements of near-surface currents (Tapia et al., 2004).

Barotropic tides are a driving force that causes internal waves. In thermally stratified waters, the flow over topographic features of the bottom produces waves in the thermocline that can be topographically trapped. At slack tide the waves are released and progress towards the coast. It has been proposed that neustonic organisms and other materials at the surface can be trapped and carried by the convergence zone that develops at the trailing edge of the waves and carried across the shelf (Shanks, 1983, 1988). Since the formation of internal waves is related to tidal range, this transport mechanism would result in fortnight pulses of supply and settlement into coastal habitats. In the case of linear, low amplitude internal waves, particles at the surface pass into and out of the convergence zone and mass transport does not occur (Franks, 1997). In large amplitude internal waves, however, bottom stress may cause strong asymmetry and non-linearity of the wave, so that the speed of the surface current generated by the wave is higher than the phase speed, resulting in accumulation of particles at the trailing edge and onshore transport (Pineda, 1999; Helfrich and Pineda, 2003). This mechanism only operates provided the larvae are neustonic, such as the case of some decapod megalopae (Zeldis and Jillett, 1982; Shanks, 1985). Inferences of the ability of internal waves to transport larvae across the shelf have been usually based on direct measurements of concentration of larvae across the fronts and surface slicks that they generate, as well as on measurements of current velocities (Shanks, 1983, 1988; Pineda, 1999; Helfrich and Pineda, 2003), but in some instances on analysis of settlement periodicity and correlations between settlement and tidal range (Shanks, 1998).

As internal tidal waves approach shallow areas they break, producing internal tidal bores. Internal bores produce near-shore upwelling of subsurface waters that may wash ashore larvae that reside below the thermocline (Pineda, 1991). The subsequent downwelling of the denser cool water then causes onshore flow at the surface, and in this case neustonic larvae may be transported onshore (Pineda, 1994). Both processes result in fortnight cycles of supply of larvae. However, formation of internal bores at the coast does not necessarily occur more often around spring tides (Pineda, 1991, 1995). The justification for this observation is that spring tides tend to disrupt the thermocline because of strong mixing, causing the internal waves to dissipate far from the shore. These studies have demonstrated correlations between settlement events and decreases or increases in water temperature in response to the internal motions (Pineda, 1991, 1994), and have been supplemented by measurements of abundance of larvae (Pineda, 1994, 1999).

Most of the studies on across-shelf translocation of larvae reviewed above emphasize the importance of concentration and transport processes by moving frontal structures. There are two key elements in these transport mechanisms. One is that there is downwelling at one or at the two sides of the front. In the case of upwelling fronts Shanks et al. (2000) consider downwelling at both sides: at the leading edge the upwelled water is displaced downward by the advancing front; at the trailing edge the fluid surface velocity is greater than the front velocity resulting in convergence and, because of mass continuity, downwelling. In the warm front produced by internal tidal bores similar processes occur (Pineda, 1999), with convergence at the trailing edge followed by downwelling at the front. The other key element is that larvae be able to maintain depth and swim against the downward flow, otherwise they would be carried down out of the convergence zones and would not concentrate. Estimates of downwelling velocities range from $0.5 \mathrm{~cm} \mathrm{~s}^{-1}$ behind upwelling fronts (Shanks et al., 2000), to $2 \mathrm{~cm} \mathrm{~s}^{-1}$ at warm bore fronts (Pineda, 1999). Available evidence on larval swimming velocities appear to support the contention that some invertebrate larvae are sufficiently strong swimmers to maintain a surface distribution in such conditions (Mileikovsky, 1973; Chia et al., 1984). In particular, reported swimming velocities of crab megalopae range from 3 to $4 \mathrm{~cm} \mathrm{~s}^{-1}$, and of cirriped cyprids are about $1-5 \mathrm{~cm} \mathrm{~s}^{-1}$ (Mileikovsky, 1973; Chia et al., 1984; Walker, 2004).

In addition to the advective transport mechanisms identified above, translocation of larvae to the nearshore can also be accomplished by eddy circulation, eddy diffusion and active directional swimming. Settlement events of fish larvae coincident with the collision with the coast of eddies spun-off by shelf and slope currents have been described in some island environments (Sponaugle et al., 2005), but have not received particular attention in other environments. Eddies have, however, been described in some cases as promoting 
retention of larvae in the shelf (Chiswell and Booth, 1999; Wing et al., 1995a; Nishimoto and Washburn, 2002) but in these cases it is implicit that a different mechanism accounts for the transport from the accumulation areas to the settlement habitats. Diffusive processes could, in theory, result in a steady flux of small larvae, but the general view is that diffusion is insufficient to transport larvae shoreward (Okubo, 1994). Larger larvae, such as decapod megalopae and post-larvae, can achieve large swimming speeds. However, except in the case of spiny lobster pueruli (Serfling and Ford, 1975; Phillips and Pearce, 1997) and lobster post-larvae (Cobb et al., 1989), which may live for weeks to months before metamorphosis and are capable of sustaining swimming speeds in excess of $10 \mathrm{~cm} \mathrm{~s}^{-1}$, directional shoreward swimming has never been convincingly supported.

\subsection{Supply into estuaries}

Contrary to larvae of organisms living in shores of the open coast, estuarine organisms still have to solve an extra problem after having been transported to the near-shore environment: how to find estuarine inlets and travel upstream. The currently accepted view is that invertebrate and fish larvae migrate into estuaries using selective tidal stream transport (STST, reviewed by Forward and Tankersley, 2001). During upstream STST, larvae settle on, or move close to, the bottom during ebb tide, to avoid being displaced seaward, and they ascend in the water column during flood tide.

The best description of the bio-physical control of STST is available from a series of field and laboratory studies on crab megalopae. These larvae are consistently more abundant in estuaries during night flood tides than at other times (e.g., Little and Epifanio, 1991; Queiroga et al., 1994). This pattern appears to arise from a combination of inhibition of swimming activity by high light intensities, ascent in the water column triggered by increases of hydrostatic pressure and salinity during flood, and sustained swimming in the presence of high turbulence levels. Chemical substances present in estuarine water, which result from the decomposition of organic matter, inhibit swimming during the day and cause sinking to the bottom (Forward and Rittschof, 1994; Forward et al., 1997). This behavior may constitute a mechanism to concentrate megalopae close to estuarine inlets. If a coastal current mixes megalopae to the estuarine plume during the day, then the sinking behaviour in response to the estuarine water could result in settlement to the bottom. As the coastal current would keep transporting megalopae, they would accumulate in the vicinity of the estuarine inlet.

During flood tide, the concurrent increase of pressure and salinity above species-specific threshold levels triggers an ascent in the water column that promotes the transport of the megalopae into the estuary (DeVries et al., 1994; Tankersley et al., 1995). Swimming is maintained during the whole duration of the flood tide by high levels of turbulence, and during slack-after-high-water the megalopae stop swimming due to decreased turbulence levels and drop to the bottom, where they remain during the ensuing ebb tide, because the salinity drop overrides the effect of turbulence (Welch et al., 1999; Welch and Forward, 2001). In some cases endogenous rhythms synchronised with the tide also assist in upstream STST (DeVries et al., 1994). The threshold rates of increase in pressure and salinity necessary to elicit the swimming response during flood (Tankersley et al., 1995) may be the basis for the increased abundance during spring tides and for the clear 2 week pattern detected in meso-tidal systems (Moser and Macintosh, 2001; Paula et al., 2001), contrasting with the diffuse pattern detected in systems with a lower tidal range (e.g., van Montfrans et al., 1995). The larger the tidal range, the higher the pressure and salinity increase rates during flood, and the more likely crab megalopae respond by swimming from the bottom to the water column.

\section{Dispersal and supply of crab and barnacle larvae in western Iberia: hypotheses and methods}

The west coast of Iberia is located on the northernmost limit of the Eastern North Atlantic Upwelling Region, which is characterized by strong and frequent upwelling events during spring and summer (Fiúza et al., 1982; Wooster et al., 1976). Tides in the region are semidiurnal, with maximum ranges spanning from less than $1 \mathrm{~m}$ during neap tides to over $3 \mathrm{~m}$ in spring tides. Other significant aspects of the coastal circulation in the area are the Portugal Current flowing off the continental slope westward of $10^{\circ} \mathrm{W}$ (Saunders, 1982), the Iberian Poleward Current (also known as the Portugal Coastal Counter Current) that flows over the slope (Frouin et al., 1990; Haynes and Barton, 1990; Ambar and Fiúza, 1994) and the Western Iberia Buoyant Plume (WIBP, Peliz et al., 2002). The Portugal Current is a slow flow that connects the North Atlantic Current 
with the Azores Current. The poleward current results from the geostrophic adjustment of the meridional pressure gradient. This gradient has higher values to the south, causing an eastward advection that is diverted to the north when it encounters the slope. This current extends to the shelf during autumn and winter, in response to strong southwest winds caused by the passage of cold fronts. During spring and summer, as the upwelling regime intensifies the southward wind-driven current flows over the poleward current and pushes it offshore. The WIBP is originated by the runoff of the many fresh water sources in the area and is perceived as a lens of low salinity water. It persists year round, albeit being less conspicuous during summer. The WIBP has been poorly studied but appears to interact in a complex manner with upwelling/downwelling circulation and may extend its influence to the area of the Portugal Coastal Counter Current. Fig. 1 summarises the major components of the upper ocean circulation off the west coast of the Iberian Peninsula during spring and early summer.

Upwelling/downwelling wind-driven circulation and tides are recurrent physical processes in western Iberia and are amongst the most energetic phenomena that can affect near-shore circulation during spring and summer. Therefore, our two first hypotheses on recruitment of barnacle and crab larvae in the west coast of Iberia were that supply should be related to wind- and tide-driven circulations. The first hypothesis was that supply to coastal sites was associated with relaxation of upwelling winds. Specifically, we should expect higher settlement or supply events following southerly winds and coincident with increased sea water temperatures. This prediction derives directly from upwelling/downwelling theory and was not tested previously with coastal invertebrates except in the west coast of the USA (e.g., Farrell et al., 1991; Wing et al., 1995b; Shanks et al., 2000). The second hypothesis was that supply to estuaries should follow a semilunar pattern. This could happen either because of (i) across-shelf transport by internal waves, (ii) near-shore transport events related with internal tidal bores, or (iii) selective tidal stream transport.

These hypotheses were tested in two regions of the west coast of Portugal: in the Ria de Aveiro and in nearby artificial rocky beaches in the north, and in the Mira Estuary and in rocky shores of Sines in the south.
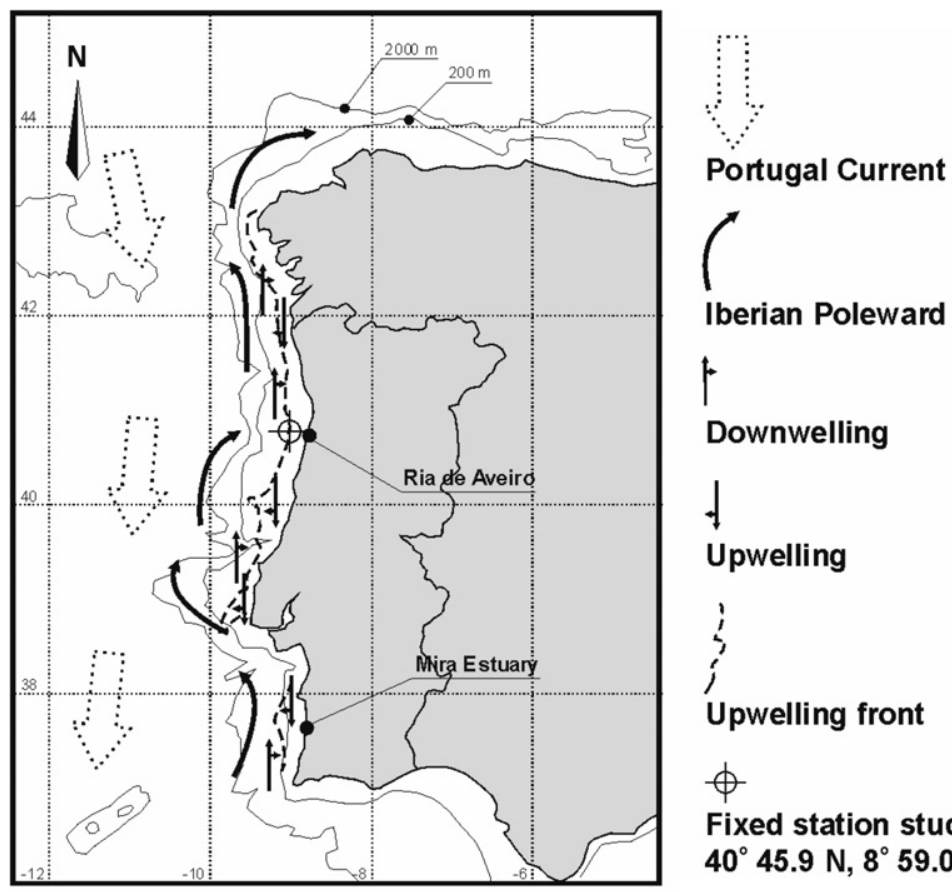

Iberian Poleward Current

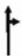

Downwelling

t

Upwelling

i

Upwelling front

$\phi$

Fixed station study at

$40^{\circ} 45.9 \mathrm{~N}, 8^{\circ} 59.0 \mathrm{~W}$

Fig. 1. Simplified diagram of the major components of the upper ocean circulation in the western Iberian coast, during spring and early summer. The upwelling front starts developing after the spring transition, when thermal stratification of the water column sets in, in response to northerly, upwelling favourable winds. As summer proceeds, northerly wind events increase in intensity and length, the upwelling front migrates seaward, and extensive upwelling filaments develop. Upwelling alternates with downwelling episodes driven by southerly winds. The Western Iberian Buoyant Plume is not represented. The diagram also shows the location of the Ria de Aveiro, the Mira Estuary and the fixed station off the Ria de Aveiro (see text for further explanation). 
These two regions are separated by about $500 \mathrm{~km}$. Settlement of Chthamalus spp. in two shores of each region was measured in $5 \times 5 \mathrm{~cm}$ squares of safety walk tape glued to PVC plates that were screwed to the rock. Settlement substrates were replaced every day at diurnal low tide from July to August of 2002 and 2003, in order to obtain measures of daily settlement during the reproductive season (Cruz, 2003). Supply of Carcinus maenas megalopae to the Ria de Aveiro and the Mira Estuary was measured daily using passive plankton nets, at one site in each estuary, from March to July of 2002. These nets were specifically designed to sample only during flood and were deployed at diurnal low tide. A trapping mechanism prevented the plankton to escape the nets during ebb periods. Settlement of megalopae was also measured every day, using $50 \times 40 \mathrm{~cm}$ rectangles of "hoghair" air conditioning filter that were deployed in different intertidal habitats (Queiroga et al., 2006). Concurrent observations of wind velocity and direction, sea level and seawater temperature were obtained at each region in both studies.

Our third hypothesis was based on the recognition that transport across the shelf depends critically on vertical position of larvae. There are clear indications that crab larvae perform extensive diel vertical migrations, which are supported both by observations in the field and by well studied morphological and behavioural adaptations (Queiroga and Blanton, 2005). Furthermore, barnacle larvae, especially the cyprid stage, are also well equipped to perform migrations of this type (Rawlinson et al., 2005). Therefore, our hypothesis was that both crab and barnacle larvae undergo diel vertical migrations (DVM) in shelf waters. The direct test of this hypothesis has been rarely attempted before in the field, and previous efforts have been mostly based on neuston samples and/or sampling of discrete depth levels (Le Reste, 1965; Shanks, 1986; Jamieson and Phillips, 1988; Abelló and Guerao, 1999; Le Reste, 1965; Rawlinson et al., 2005).

In order to investigate this hypothesis, a grid of stations arranged into four across-shelf transects was set off the Aveiro coast. Additionally, a mooring equipped with CTD and current recorders was positioned at $21 \mathrm{~km}$ from the coast at a bottom depth of $63 \mathrm{~m}$. The grid was sampled in May 2002 using CDT recorders and a WP2 plankton net, in order to obtain a quasi-synoptic view of mesoscale circulation patterns and larval availability. After sampling the grid, a fixed station close to the mooring was occupied for $69 \mathrm{~h}$. During this period, a LHPR was towed obliquely from $10 \mathrm{~m}$ above the bottom to the surface, every two hours. A neuston net was deployed immediately after the LHPR. CTD profiles of the water column were obtained every hour of the fixed station study (dos Santos et al., submitted for publication, 2007; Santos et al., 2006).

\section{Physical correlates between years and regions}

Physical data indicated that the response of the coastal ocean to wind stress in the northern and southern coasts was similar in both years. The following observations are reported in Cruz (2003) and in Queiroga et al. (2006). NNW winds dominated during the study periods in both regions. Correlations between satellite derived SST and along shore wind stress indicated that a decrease in temperature occurred usually one day after intensification of northerly winds in both regions. Nearshore temperature measured in situ was also correlated with wind stress. In Sines, daily SST was correlated with along-shore wind stress at time lags of 1 and 3 days, in 2002 and 2003 respectively. In Aveiro, daily SST was correlated with wind stress at a time lag of 1 day in both years. Additionally, in 2002 spectral analysis of the along-shore wind component indicated spectral density peaks at periods of 2-9 days. These observations indicate the occurrence of intermittent upwelling during the larval season at both locations and study periods.

Tides have similar ranges throughout all the west coast of the Iberian Peninsula. For practical purposes tides are synchronised along the coast, with a delay of about $20 \mathrm{~min}$ in the northern coast, as determined from the tide tables of the Instituto Hidrográfico (Portugal) and from Marta-Almeida and Dubert (2006).

\section{Barnacle larvae}

\subsection{Patterns of recruitment to littoral populations}

The following set of observations is reported in Cruz (2003). This study tested the predictions of three models explaining supply and settlement rates of Chthamalus spp. in Aveiro and in Sines. The first model was that settlement is correlated with upwelling/downwelling circulation. Upwelling days were defined based 
on intensity of alongshore wind stress during the previous day. The prediction was that settlement rate should be higher in non-upwelling days and coincident with higher near-shore temperatures. The model was not supported in 2002 neither at Aveiro nor Sines: no differences in settlement rate were observed between upwelling and non-upwelling days, and settlement rate was not positively correlated with water temperature. The model was only partially supported in 2003 in both regions, when a positive correlation between settlement and temperature was detected, but when settlement during non-upwelling days was not higher than in upwelling days.

The second model was that supply is provided via internal tidal bores propagating onshore. This model predicts that there should be a fortnight pattern in settlement rate, and that settlement rate should be higher with lower nearshore temperature, because bores produce nearshore upwelling of cool water. This model again was not totally supported. In 2002 there was a positive correlation between settlement and tidal range at both regions, indicating a semilunar pattern of settlement; however, settlement was not negatively correlated with temperature. In 2003 settlement was correlated with tidal range at Aveiro, but not at Sines. This model also predicts that if supply is related to internal tidal bores, then settlement should be positively correlated both with the temperature difference between surface and bottom waters and with variance of midwater temperature, which are indicators of internal motions. This prediction was tested in Sines in 2003 and was supported by the observations.

According to the third model, supply is controlled by the sea breeze. Observations made during a study (D. Jacinto and T. Cruz, unpublished observations) that was conducted in parallel with the Cruz (2003) observations, found that settlement was highest during afternoon high tide and detected a positive significant correlation between settlement during one tidal cycle and onshore wind stress. Since afternoon high tides are large amplitude tides in the Portuguese coast, and the sea breeze is most intense during this part of the day, these results support the sea breeze model. However in the study of Cruz (2003), daily settlement was not correlated with onshore wind stress indicating a probable lack of resolution of the daily scale to understand processes that operate at a smaller scale.

In summary, the three models that were investigated for the supply of Chthamalus spp. larvae to coastal habitats (upwelling/downwelling circulation, internal tidal bores and sea breezes) were not totally supported nor totally rejected in both regions and years. This indicates that further research is needed to test other alternative or complementary hypotheses derived from these models. The data reviewed here show that settlement was correlated among shores at each location and year, indicating that a common mechanism is responsible for supply to shores separated by several $\mathrm{kms}$. This is usually regarded as evidence that the mechanism(s) in question is related to across-shelf transport controlled by mesoscale processes, and not by local hydrodynamic factors (Pineda, 2000).

\subsection{Patterns of vertical distribution in the shelf}

The study of dos Santos et al. (2007) in shelf waters off Aveiro identified three size groups of cyprid larvae that were assigned to different species groups: one group assigned to Chthamalus montagui and Pollicipes pollicipes, a second group comprised of C. stellatus, and another comprised mainly by Balanus perforatus cyprids. C. stellatus cyprids were the most numerous group, occurring from the neuston layer down to $55 \mathrm{~m}$. These larvae showed a pronounced vertical migration behaviour synchronised with the day cycle: they were more abundant by night from the surface to $20 \mathrm{~m}$, while below $20 \mathrm{~m}$ they were always more abundant during the day. Additionally, the proportion of $C$. stellatus cyprids in the neuston was very low during day time. The vertical migration pattern displayed by these larvae did not appear to be affected by physical conditions in the water column, although some differences in vertical distribution between days were related to varying light penetration conditions. Cyprids assigned to Chthamalus montagui, Pollicipes pollicipes and Balanus perforatus were largely restricted to the neuston layer and showed only low-amplitude vertical migration. This study was the first to specifically address variations of barnacle cyprids abundance and distribution along the water column. It showed that different species may exhibit different behavioural patterns of migration. Assignment of cyprid forms to species level based on size criteria tentatively enable the conclusions that $C$. montagui are mostly neustonic organisms, and that $C$. stellatus perform diel vertical migrations along the water column. 
Another finding of dos Santos et al. (2007) was that cyprid larvae were much more common along the inner shelf, up to $30 \mathrm{~km}$ offshore. This distribution pattern was considered to result from upwelling-favourable wind conditions that create fronts along the shelf, which prevent the offshore advection of the larvae.

\section{Crab larvae}

\subsection{Patterns of recruitment to littoral populations}

Supply patterns of Carcinus maenas megalopae to the Ria de Aveiro and the Mira Estuary were described by Queiroga et al. (2006). This study found clear events of supply in both estuaries that were separated by periods of 14-15 days and occurred around full and new moons. Cross-correlograms between supply and tidal range showed maximum values at lags of 0 and 15 days, although correlation values for the Mira Estuary were below those expected from white noise estimates. Because of the time lag of 0 days between maximum supply and maximum tidal range the supply events were interpreted as resulting from STST. The mechanism would be that megalopae had been transported across the shelf and close to estuarine inlets by some other mechanism, and then would react to the increase in pressure and salinity during flood spring tides by swimming more in the water column, resulting in an immediate supply to the estuary (DeVries et al., 1994; Welch and Forward, 2001; Tankersley et al., 2002). Based on the fortnight periodicity of supply, the possibility that internal waves and bores were involved (Shanks, 1983; Pineda, 1995) could not be entirely dismissed. This however would be a less parsimonious explanation, because it would have to assume a complex relationship between the phasing of these phenomena relative to the spring/neap cycle and the duration of the transport across the shelf. The delay of zero days between tidal range and supply was also similar to that involved in supply of crab megalopae to most estuaries measured in the studies of Moser and Macintosh (2001), Paula et al. (2001) and van Montfrans et al. (1995), but differed from that recorded by Miller and Shanks (2004). If supply is controlled by tidal range, and this cycle is synchronised in both regions, then supply should be correlated across regions. This was not the case, and the suggested cause was differences in larval availability between regions.

Given the clear semilunar signal imbedded in the time series of supply, the effect of along-shore winds on supply was analysed after removing the periodic component. This was done by a multiple regression model including terms to account for the semilunar cycle and wind stress. The analysis showed significant effects of wind stress at time lags of 0-2 days and a possible cumulative effect of wind events lasting 2-4 days. In all time lags and in both regions, supply increased after southerly winds. The signal of the association and the time lags were in accordance with the expectations of the general theory of upwelling/downwelling circulation (Wooster et al., 1976) and with observations made in the Portuguese coast (Fiúza, 1984; Jorge da Silva, 1992). The possible interaction of wind-driven transport and position of larvae in the water column is discussed below.

A final conclusion of this study was that settlement of $C$. maenas was synchronised across intertidal habitats inside the estuaries, but was decoupled from supply. The reasons for the decoupling between supply and settlement were not clear. Possible causes could be turbulence levels preventing settlement during spring tides (Welch et al., 1999), differences in the physiological state of the megalopae (Forward et al., 2001) and density-dependent secondary dispersal (Turner et al., 1997).

\subsection{Patterns of vertical distribution in the shelf and consequences for horizontal dispersal}

Very few Carcinus maenas larvae were found in the shelf off Aveiro during the period of study (dos Santos et al., submitted for publication). However, large numbers of zoeae and megalopae of other decapod species occurred in the samples. The larvae of all decapods collected during the fixed station study were pooled keeping zoeae separated from megalopae, and the aggregated data sets were investigated for patterns of vertical distribution through time. Abundance of zoeae and megalopae during the night was 3 and 8 times higher than during the day, respectively. Both stages were virtually absent from the top half of the water column during the day and depicted large concentrations during the night. During two of the three days of the study up to 1000 -fold increases of zoeae and megalopae in the neuston layer were observed immediately after sunset. Concentrations in the neuston peaked between 0:00 and 2:00 and decreased suddenly before sunrise. The 
consistent paucity of larvae in the water column and their deep distribution during the day suggested that both zoeae and megalopae moved to a narrow layer between a depth of $55 \mathrm{~m}$, which was the deepest level sampled by the LHPR, and the bottom at $63 \mathrm{~m}$. These observations indicate a very strong pattern of vertical migration synchronised with the day cycle, with ascent in the water column from close to the bottom starting before sunset and descent from the upper layers starting before sunrise. The study could not demonstrate any association of vertical position of the larvae, as measured by their average depth of distribution, with the depth of the thermocline, of the halocline and of the maximum chlorophyll- $a$ concentration, nor with radiation levels, average chlorophyll- $a$ concentration and average biovolume. At the same time an increase in the average depth of distribution of the zoeae was significantly correlated with increasing wind velocity.

An important conclusion of the study was that most decapod zoeae and megalopae were not neustonic, even during the night. Although concentrations in the neuston layer during the night were higher, this layer represents only $0.2 \mathrm{~m}$ of a water column $63 \mathrm{~m}$ high, meaning that the total number of larvae below the surface layer was one order of magnitude larger than that at the surface, for both stages. This conclusion was based on data aggregating several species, and care should therefore be exercised when extrapolating to particular taxa. Even so, this finding challenges the common belief that decapod megalopae are mostly neustonic organisms. The pattern observed in the study was strongly influenced by brachyuran zoeae and megalopae, which accounted for up to $54 \%$ of the larvae. Several of the larvae in this group belonged to coastal species.

The strong pattern of vertical migration that spanned most part of the water column raised the hypothesis that these movements could provide a way of reducing wastage from shelf waters of an upwelling system. The rationale was that, by partitioning the time between the surface layer, with a predominantly seaward flow, and the bottom onshore compensating current, the larvae would be retained in shelf waters. Marta-Almeida et al. (2006) investigated this hypothesis using a 3-D numerical model of circulation in the northwestern Iberian Peninsula (Regional Ocean Modelling System) coupled with an individual based model simulating larval behaviour. The model did not include tidal currents, which were previously shown not to significantly affect advection at the time scale of larval development time, and was forced by heat fluxes with the atmosphere and real winds. The model contrasted the effect of wind regimes typical of upwelling and non-upwelling seasons, as well as different types of nocturnal diel vertical migration (DVM). The prediction of the model was that, during the upwelling season, the proportion of larvae undergoing DVM that was retained in the inner shelf, which was defined as a $5 \mathrm{~km}$-wide coastal strip, was much higher than in any other combination of migration behaviour and wind regime. Thence, for a rocky shore or estuarine crab whose larvae develop for an average of 5 weeks in the plankton and display pronounced DVM, upwelling potentially improves recruitment. This prediction contradicts the paradigm that stronger upwelling is associated with decreased recruitment levels to populations of coastal species (Connolly and Roughgarden, 1998; Connolly et al., 2001).

Validation of the circulation and behavioural models was accomplished in two ways. The first was by comparing predictions of current velocities with observations made at the mooring deployed at the fixed station study over the shelf (dos Santos et al., submitted for publication, 2007). The comparison showed that simulated currents agreed generally well with the observations (Marta-Almeida et al., 2006). The second is reported in Peliz et al. (2006) and was performed by comparing predictions of larval distributions over the shelf with distributions observed during a cruise conducted off the northern coast of Portugal in April of 1991 (Queiroga, 1996). In this case the behavioural model assumed that the larvae performed DVM between the surface and the bottom. Again, the oceanographic model was forced by observed winds and heat fluxes during the relevant period, and included also climatological values of freshwater runoff from the rivers in the region. The major dispersion patterns that were observed were reproduced by the model, notably the number and position of the elongated patches of larvae parallel to the coast inshore of the $100 \mathrm{~m}$ isobath (Peliz et al., 2006).

\section{Generality and significance}

\subsection{DVM and potential concentration at fronts}

To our knowledge, the studies by dos Santos et al. (submitted for publication, 2007) are the only available in the literature that comprehensively address the problem of describing changes of vertical distribution of larvae along the whole water column using a methodology that effectively decomposes the distribution of the lar- 
vae into vertically integrated strata. The studies showed that decapod zoeae and megalopae, as well as $C$. stellatus cyprids, displayed a strong DVM along most of a water column $63 \mathrm{~m}$ high located in the middle shelf. Such pattern had never been previously described in barnacle cyprids. Contrasting to the general lack of information regarding larval behaviour of barnacle larvae, a wealth of information is available for decapod crustacean larvae. DVM behaviour appears to be the general rule in larvae of this group, although such clear pattern has seldom been described (see Queiroga and Blanton, 2005, but also Rimmer and Phillips, 1979; Booth et al., 1985; Shanks, 1986; Abelló and Guerao, 1999).

These findings raise the question of the significance of fronts as mechanisms able to concentrate and transport larvae of these organisms across the shelf. Concentration of larvae in frontal structures requires some type of depth keeping behaviour within the zone affected by the convergence flows. For larvae undergoing DVM this may happen at the surface during the night, but for the rest of the day the larvae will either be actively changing position or deep in the water column and, in the latter case, probably outside the area affected by the convergence flows. This is obviously an aspect that requires further attention, particularly in what concerns: (i) what proportions of larvae are retained in frontal zones versus those that are not found at the fronts; (ii) do these proportions differ according to phase of day; and (iii) how do these proportions differ according to position in the shelf, vertical extent of the front and water depth. Clearly, our appreciation of the relative importance of upwelling fronts, internal waves and internal tidal bores on the onshore transport of larvae depends on a better understanding of these questions.

In the case of decapod larvae, the problem of trapping at the convergence zones can be examined more closely. The fixed station study could not demonstrate any effect of thermo-haline stratification, phytoplankton biomass or zooplankton volume on the extent of the migration nor in the average position of the larvae. Available data indicate that these larvae perform vertical migrations quite independently from the thermal properties of the water that they traverse, with some larvae even crossing very unrealistic laboratory gradients of $10^{\circ} \mathrm{C}$ over distances of less than $1 \mathrm{~m}$ (Kelly et al., 1982; Sulkin et al., 1983; McConnaughey and Sulkin, 1984; Jamieson and Phillips, 1993). However, haloclines involving differences as small as 1 ppt may prevent them from ascending to the surface (Hughes, 1969; Roberts, 1971), inhibiting, rather than promoting, larvae to ascend to surface convergent flows. Radiation at the surface was also not related to the average depth distribution of the larvae, indicating that it may act as the trigger for the start of the vertical movements, but that the average depth of distribution is governed by other factors (Forward, 1976). Both the span and the speed of the movements described by the fixed station study are consistent with the swimming velocities reported in the literature (Mileikovsky, 1973; Chia et al., 1984). Therefore, based on the data presented by dos Santos et al. (submitted for publication), as well as on the behavioural reactions described in the literature, there is no reason to believe that in general decapod zoeae and megalopae have the tendency to be trapped at frontal convergence zones as described elsewhere (Helfrich and Pineda, 2003; Pineda, 1999; Shanks, 1983, 1988; Shanks et al., 2000; Santos et al., 2004). The possibility is still open that changes in the flow structure, such as accelerations, shear stress or turbulence, might modify the behaviours usually displayed by pelagic larvae, but this is a novel field of research for which information appears to be totally missing.

Having said this, we reiterate that care has to be exercised when looking at specific cases. There are several possible sources of uncertainty when we make inferences on the types and significance of vertical migration behaviour. For instance, the clear pattern identified for the aggregated data on zoeae and megalopae is much more difficult to demonstrate when we look at particular species, and even more so when we consider individual stages, due to the low concentrations in which these larvae often occur. There certainly is interspecific variation in these patterns, and in some cases at higher taxonomic levels. Stage IV larvae of the Astacidae (Cobb et al., 1983, 1989) and pueruli of the Palinura (Serfling and Ford, 1975; Calinski and Lyons, 1983) appear to be truly neustonic for most of the time, having been reported to swim directionally just below the surface, and megalopae of some Grapsidae swam directly to the surface when released underwater during daytime (Shanks, 1985).

\subsection{DVM and upwelling/downwelling circulation}

In view of the patterns of DVM identified in the fixed station study, it appears a strong possibility that comparatively strong swimmers such as crab larvae can mitigate seaward transport by alternating between the sur- 
face and bottom layers. The mechanism that partitioning of the time between the upper and lower layers could contribute to retention of plankton in shelf waters of upwelling systems had been originally proposed by Peterson (1998) and was examined by the modelling study of Marta-Almeida et al. (2006). The interesting result of the model is that if crab larvae do indeed perform DVM as described, then upwelling may actually enhance retention of larvae in the inner shelf. This mechanism could be the basis for the short delays (0-2 days) between increasing southerly winds and increasing supply of Carcinus maenas larvae to the estuaries on the west coast of Portugal (Huthnance et al., 2002; Queiroga et al., 2006). Fig. 2 shows a two-layer model for across-shelf dispersal of $C$. maenas larvae during upwelling and downwelling, and Fig. 3 summarises the current understanding of the factors that affect the different processes of the larval phase of this species in western Iberia.

Retention of larvae during upwelling could be the basis for the mismatch between the timing of production of Carcinus maenas larvae (which commences in November/December) and the start of major recruitment events from April onwards (Sprung, 2001). This mismatch could partly be explained if the onset of the upwelling season aids in the retention of vertical migrating crab larvae in shelf waters. Climatological upwelling indices calculated for the Portuguese coast (Huthnance et al., 2002) indicate that persistent upwelling events may start as early as March to May, and these could set the conditions for successful recruitment of the species.

\subsection{Neustonic distribution, internal tidal bores and sea breezes}

The fixed station study also indicated that Chthamalus montagui, Balanus perforatus andPollicipes pollicipes cyprids appear to be mostly neustonic organisms (dos Santos et al., 2007). A neustonic distribution of the cyprid stage lends support to the interpretation that dispersal of $C$. montagui over the shelf may be controlled by variable winds, sea breezes and internal tidal waves and bores. Approximately down-wind transport in the neuston layer would result in the spread of the larvae throughout the shelf, and upwelling fronts colliding with the coast during downwelling, internal motions, and the sea breeze may cause onshore transport. The existence of multiple controls could be responsible for a large variability of the supply and settlement events recorded in the northern and southern coasts (Cruz, 2003).
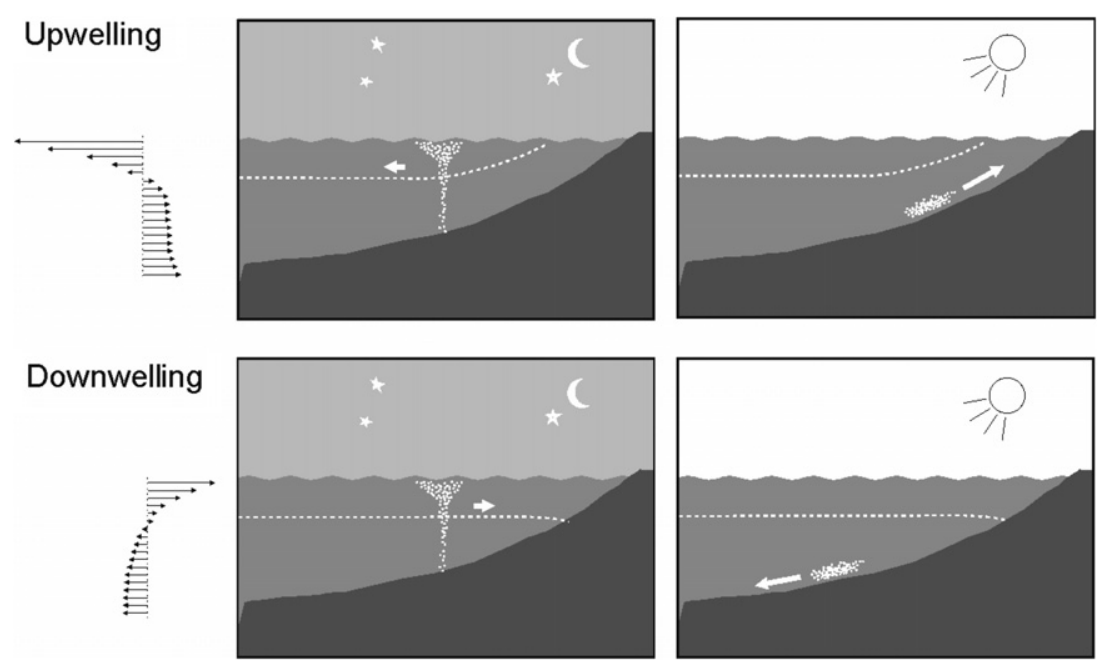

Fig. 2. Two-layer model for across-shelf dispersal of Carcinus maenas larvae during upwelling and downwelling. The model assumes that the larvae undergo diurnal vertical migration controlled by sunrise and sunset times (longer period of time spent in bottom waters during daytime, in spring and summer), and that the pattern does not change with larval stage. During upwelling, the long period of time spent during the day in the bottom counter-current overcompensates the seaward displacement at surface during the night, and the larvae are kept in the inner shelf. During downwelling the vertical current pattern is reversed and the net transport of the larvae is seaward. The figure shows cross-sections of the shelf; white thick arrows in each panel represent transport of the larvae; arrows at left represent vertical distribution of the across-shelf component of current velocity. 


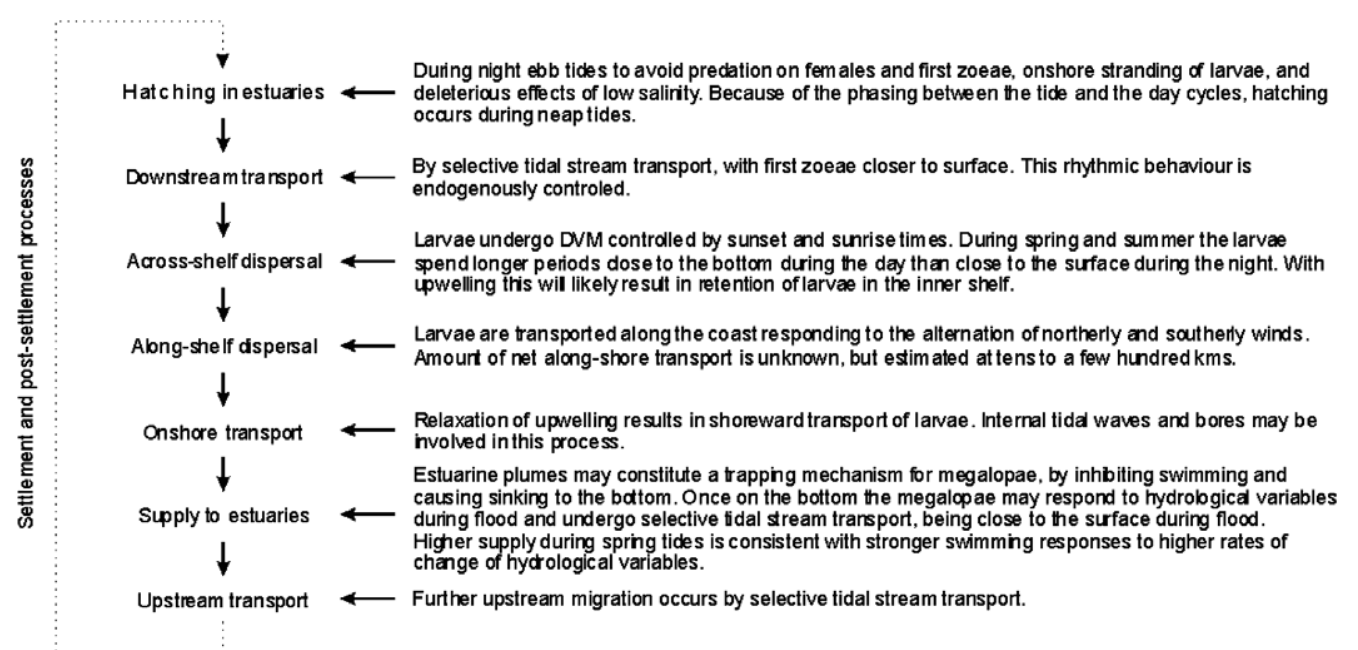

Fig. 3. Summary of the present understanding of the factors that affect dispersal of Carcinus maenas larvae in the western Iberian coast.

\subsection{Larval pool assumptions}

Most studies on shoreward advection and supply of larvae assume an available pool from where the larvae are supplied. Pineda (2000) examined the advantages and shortcomings involved in the "larval pool" simplification. This concept assumes that larvae accumulate in an offshore region until some process acting on the larvae and on the water mass advects them towards the nearshore adult habitats. At the present state of knowledge and technical development it is virtually impossible to assign a point source to the larvae that accumulate in the pool. Consequently, inferences on the origin of the larvae that accumulate in the pool can only be made at a broad spatial scale. When different origins can be assumed in such cases, then it would be probably more fitting to assume separate pools. In the study of supply and settlement in the two estuaries separated by more than $500 \mathrm{~km}$ on the west coast of Portugal (Queiroga et al., 2006) supply was 18 times higher in the Mira estuary located in the south than in the Ria de Aveiro in the north. Similarly, daily settlement rate of Chthamalus at Sines was 39 times higher than at the Aveiro area (Cruz, 2003). Previously, Queiroga (1996) found concentrations of Carcinus maenas in the order of 0.02 ind $\mathrm{m}^{-3}$ in the shelf of northern Portugal and Queiroga et al. (1994) reported concentrations of 0.03 ind $\mathrm{m}^{-3}$ in the Ria de Aveiro. There are no data on abundance of $C$. maenas megalopae in the southwestern shelf, but concentrations inside the Mira estuary were one order of magnitude higher than in the Ria de Aveiro (V. Amaral, unpublished observations). In general, abundances of $C$. maenas megalopae in northern Portugal are one to three orders of magnitude lower than the abundances of the same and other portunid species in other systems (Little and Epifanio, 1991; Olmi, 1994; van Montfrans et al., 1995; Moksnes and Wennhage, 2001), lending support to the view of a low level of larval availability and supply in the northern coast. These observations suggest large differences in the size of the larval pool between the northwestern and southwestern coasts, which may be caused by greater expanses of rocky shores and larger estuaries in southern Portugal, supporting larger populations of both species. Since larval development times are on the order of 2-3 weeks in Chthamalus (Burrows et al., 1999) and 4-6 weeks in the case of Carcinus (Dawirs, 1985; Nagaraj, 1993), it does not appear probable that there is a regular exchange of larvae over the distance separating these two areas. Lack of knowledge on the origin of the larvae that accumulate in the pool does not hinder the investigation of the onshore movements, but has obvious disadvantages when one considers meta-population dynamics, genetic flux, fisheries, design of marine protected areas or zoogeography (Pineda, 2000).

A further point of interest regards the abundances of Chthamalus spp. cyprids recorded during the fixed station study (dos Santos et al., 2007). This study found that $C$. stellatus larvae were considerably more abundant than those of $C$. montagui. Yet, adult $C$. montagui dominate rocky shores in the Portuguese coast (Boaventura et al., 2002), leading to the expectation of higher abundances of planktonic larvae of the latter 
species. The inconsistency may be due to seasonal differences in reproduction activity between the two species close to their southern limit of distribution, and to the fact that the fixed station study spanned a period of only three days in May and may have sampled during a reproductive peak of $C$. stellatus.

\section{References}

Abelló, P., Guerao, G., 1999. Temporal variability in the vertical and mesoscale spatial distribution of crab megalopae (Crustacea: Decapoda) in the Northwestern Mediterranean. Estuarine, Coastal and Shelf Science 49, 129-139.

Almeida, M.J., Queiroga, H., 2003. Physical forcing of onshore transport of crab megalopae in the northern Portuguese upwelling system. Estuarine, Coastal and Shelf Science 57, 1091-1102.

Ambar, I., Fiúza, A.F.G., 1994. Some features of the Portugal current system: a poleward slope undercurrent, an upwelling-related summer southward flow and an autumn-winter poleward coastal surface current. In: Katsaros, K.B., Fiúza, A.F.G., Ambar, I. (Eds.), Proceedings of the Second International Conference on Air-Sea Interaction and on Meteorology and Oceanography of the Coastal Zone. American Meteorological Society, pp. 286-287.

Anger, K., 2001. The Biology of Decapod Crustacean Larvae. A.A. Balkema Publishers.

Boaventura, D., Ré, P., Da Fonseca, L.C., Hawkins, S.J., 2002. Intertidal rocky shore communities of the continental Portuguese coast: analysis of distribution patterns. Marine Ecology-Pubblicazioni Della Stazione Zoologica Di Napoli I 23, 69-90.

Boehlert, G.W., Mundy, B.C., 1988. Roles of behavioural and physical factors in larval and juvenile fish recruitment to estuarine nursery areas. American Fisheries Society Symposium 3, 51-67.

Boidron-Métairon, I.F., 1995. Larval nutrition. In: McEdward, L. (Ed.), Ecology of Marine Invertebrate Larvae. CRC Press, Boca Raton, FL, USA, pp. 223-248.

Booth, J.D., Phillips, A.C., Jamieson, G.S., 1985. Fine scale spatial distribution of Cancer magister megalopae and its relevance to sampling methodology. Alaska Sea Grant Report 85, 273-286.

Burrows, M.T., Hawkins, S.J., Southward, A.J., 1992. A comparison of reproduction in cooccurring chthamalid barnacles, Chthamalus stellatus (Poli) and Chthamalus montagui southward. Journal of Experimental Marine Biology and Ecology 160, $229-249$.

Burrows, M.T., Hawkins, S.J., Southward, A.J., 1999. Larval development of the intertidal barnacles Chthamalus stellatus and Chthamalus montagui. Journal of the Marine Biological Association of the United Kingdom 79, 93-101.

Calinski, M.D., Lyons, W.G., 1983. Swimming behavior of the puerulus of the spiny lobster Panulirus argus (Latreille, 1804) (Crustacea: Palinuridae). Journal of Crustacean Biology 3, 329-335.

Chia, F.-S., Buckland-Nicks, J., Young, C.M., 1984. Locomotion of marine invertebrate larvae: a review. Canadian Journal of Zoology 62, 1205-1222.

Chiswell, S.M., Booth, J.D., 1999. Rock lobster Jasus edwardsii larval retention by the Wairarapa eddy off New Zealand. Marine Ecology Progress Series 183, 227-240.

Cobb, J.S., Gulbransen, T., Phillips, B.F., Wang, D., Syslo, M., 1983. Behavior and distribution of larval and early juvenile Homarus americanus. Canadian Journal of Fisheries and Aquatic Sciences 40, 2184-2188.

Cobb, J.S., Wang, D., Campbell, D.B., Rooney, P., 1989. Speed and direction of swimming by postlarvae of the American lobster. Transactions of the American Fisheries Society 118, 82-86.

Connell, J.H., 1985. The consequences of variation in initial settlement vs postsettlement mortality in rocky intertidal communities. Journal of Experimental Marine Biology and Ecology 93, 11-45.

Connolly, S.R., Roughgarden, J., 1998. A latitudinal gradient in northeast Pacific intertidal community structure: evidence for an oceanographically based synthesis of marine community theory. American Naturalist 151, 311-326.

Connolly, S.R., Menge, B.A., Roughgarden, J., 2001. A latitudinal gradient in recruitment of intertidal invertebrates in the northeast Pacific Ocean. Ecology 82, 1799-1813.

Cruz, T., 1999. Settlement patterns of Chthamalus spp. at praia da oliveirinha (Sw Portugal). Acta Oecologica-International Journal of Ecology 20, 285-287.

Cruz, T., 2003. Padrões espaciais e temporais de recrutamento de larvas de cracas. In: Queiroga, H. et al. (Eds.), The ProRecruit Project. Shelf processes controlling recruitment to littoral populations in an eastern oceanic boundary: using barnacles and crabs as models. $2^{\circ}$ Relatório de Execução Material, University of Aveiro, Aveiro, Portugal, pp. 15-28 (unpublished).

Cruz, T., Castro, J.J., Delany, J., Mcgrath, D., Myers, A.A., O'riordan, R.M., Power, A.M., Rabaca, J., Hawkins, S.J., 2005. Tidal rates of settlement of the intertidal barnacles Chthamalus stellatus and Chthamalus montagui in western Europe: the influence of the night/ day cycle. Journal of Experimental Marine Biology and Ecology 318, 51-60.

Dawirs, R.R., 1985. Temperature and larval development of Carcinus maenas (Decapoda) in the laboratory; prediction of larval dynamics in the sea. Marine Ecology Progress Series 24, 297-302.

DeVries, M.C., Tankersley, R.A., Forward Jr., R.B., Kirby-Smith, W.W., Luettich Jr., R.A., 1994. Abundance of estuarine crab larvae is associated with tidal hydrologic variables. Marine Biology 118, 403-413.

dos Santos, A., Santos, A.M.P., Conway, D.V.P., 2007. Horizontal and vertical distribution of cirripede cyprid larvae in an upwelling system off the Portuguese coast. Marine Ecology Progress Series 329, 145-155.

dos Santos, A., Santos, A.M.P., Conway, D.V.P., Bartilotti, C., Lourenço, P., Queiroga, H., submitted for publication. Diel vertical migration of decapod larvae in the Portuguese coastal upwelling ecosystem. Marine Ecology Progress Series.

Farrell, T.M., Bracher, D., Roughgarden, J., 1991. Cross-self transport causes recruitment to intertidal populations in central California. Limnology and Oceanography 36, 279-288. 
Fiúza, A.F.G., 1984. Hidrologia e dinâmica das águas Costeiras de Portugal. Ph.D. Thesis, University of Lisbon.

Fiúza, A.F.G., Macedo, M.E., Guerreiro, M.R., 1982. Climatological space and time variation of the Portuguese coastal upwelling Oceanologica Acta 5, 31-40.

Forward Jr., R.B., 1976. Light and diurnal vertical migration: photobehaviour and photophysiology of plankton. In: Smith, K.C. (Ed.), Photochemical and Photobiological Reviews. Plenum Press, New York, pp. 157-209.

Forward Jr., R.B., Rittschof, D., 1994. Photoresponses of crab megalopae in offshore and estuarine waters: implications for transport. Journal of Experimental Marine Biology and Ecology 182, 183-192.

Forward Jr., R.B., Tankersley, R.A., 2001. Selective tidal-stream transport of marine animals. Oceanography and Marine Biology: An Annual Review 39, 305-353.

Forward Jr., R.B., Swanson, J., Tankersley, R.A., Welch, J.M., 1997. Endogenous swimming rhythms of blue crab, Callinectes sapidus, megalopae: effects of offshore and estuarine cues. Marine Biology 127, 621-628.

Forward Jr., R.B., Tankersley, R.A., Rittschof, D., 2001. Cues for metamorphosis of brachyuran crabs: an overview. American Zoologist $41,1108-1122$

Fraga, S., Anderson, D.M., Bravo, I., Reguera, B., Steidinger, K.A., Yentsch, C.M., 1988. Influence of upwelling relaxation on dinoflagellates and shellfish toxicity in Ria de Vigo, Spain. Estuarine Coastal and Shelf Science 27, 349-361.

Franks, P., 1997. Spatial patterns in dense algal blooms. Limnology and Oceanography 42, 1297-1305.

Frouin, R., Fiúza, A.F.G., Ambar, I., Boyd, T.J., 1990. Observation of a poleward surface current off the coast of Portugal and Spain during winter. Journal of Geophysical Research 95, 679-691.

Goodrich, D.M., Van Montfrans, J., Orth, R.J., 1989. Blue crab megalopal influx to Chesapeake Bay: evidence for a wind-driven mechanism. Estuarine, Coastal and Shelf Science 29, 247-260.

Hawkins, S.J., Hartnoll, R.G., 1982. Settlement patterns of Semibalanus balanoides (L.) in the Isle of Man (1977-1981). Journal of Experimental Marine Biology and Ecology 62, 271-283.

Haynes, R., Barton, E.D., 1990. A poleward flow along the Atlantic coast of the Iberian Peninsula. Journal of Geophysical Research 95, 11425-11441.

Helfrich, K.R., Pineda, J., 2003. Accumulation of particles in propagating fronts. Limnology and Oceanography 48, 1509-1520.

Hughes, D.A., 1969. Responses to salinity changes as a tidal transport mechanism of pink shrimp Penaeus duodarum. Biological Bulletin 136, 43-53.

Hughes, R.N., Griffiths, C.L., 1988. Self-Thinning in barnacles and mussels - the geometry of packing. American Naturalist 132, 484-491.

Huthnance, J.M., Van Aken, H.M., White, M., Barton, E.D., Le Cann, B., Coelho, E.F., Fanjul, E.A., Miller, P., Vitorino, J., 2002. Ocean margin exchange - water flux estimates. Journal of Marine Systems 32, 107-137.

Jamieson, G.S., Phillips, A.C., 1988. Occurrence of Cancer crab (C. magister and C. oregonensis) megalopae off the west coast of vancouver Island, British Columbia. Fishery Bulletin 86, 525-542.

Jamieson, G.S., Phillips, A.C., 1993. Megalopal spatial distribution and stock separation in Dungeness crab (Cancer magister). Canadian Journal of Fisheries and Aquatic Sciences 50, 416-429.

Jorge da Silva, A., 1992. Dependence of upwelling related circulation on wind forcing and stratification over the Portuguese northern shelf. ICES, ICES C.M. 1992/C: 17, 11 pp.

Kelly, P., Sulkin, S.D., van Heukelem, W.F., 1982. A dispersal model for larvae of the deep sea red crab Geryon quinquedens based upon behavioural regulation of vertical migration in the hatching stage. Marine Biology 72, 35-43.

Le Reste, L., 1965. Contribution a l'étude des larves de cirripèdes dans le Golfe de Marseille. Réceuils des Travaux de la Station Maritime d' Endoume 38, 33-121.

Little, K.T., Epifanio, C.E., 1991. Mechanism for the reinvasion of an estuary by two species of brachyuran megalopae. Marine Ecology Progress Series 68, 235-242.

Marta-Almeida, M., Dubert, J., 2006. The structure of tides in the western Iberia region. Continental Shelf Research 26, 385-400.

Marta-Almeida, M., Dubert, J., Peliz, A., Queiroga, H., 2006. Influence of vertical migration pattern on retention of crab larvae in the shelf in a seasonal upwelling system. Marine Ecology Progress Series 307, 1-19.

McConnaughey, R.A., Sulkin, S.D., 1984. Measuring the effects of thermoclines on the vertical migration of larvae of Callinectes sapidus (Brachyura, Portunidae) in the laboratory. Marine Biology 81, 139-145.

Mileikovsky, S.A., 1973. Speed of active movement of pelagic larvae of marine bottom invertebrates and their ability to regulate their vertical position. Marine Biology 23, 11-17.

Miller, J.A., Shanks, A.L., 2004. Ocean-estuary coupling in the Oregon upwelling region: abundance and transport of juvenile fish and of crab megalopae. Marine Ecology-Progress Series 271, 267-279.

Moksnes, P.-O., Wennhage, H., 2001. Methods for estimating decapod larval supply and settlement: importance of larval behaviour and development stage. Marine Ecology Progress Series 209, 257-273.

Morgan, S.G., 1995. Life and death in the plankton: larval mortality and adaptation. In: McEdward, L. (Ed.), Ecology of Marine Invertebrate Larvae. CRC Press, Boca Raton, FL, USA, pp. 279-321.

Moser, S.M., Macintosh, D.J., 2001. Diurnal and lunar patterns of larval recruitment of brachyura into a mangrove estuary system in Ranong Province, Thailand. Marine Biology 138, 827-841.

Nagaraj, M., 1993. Combined effects of temperature and salinity on the zoeal development of the green crab, Carcinus maenas (Linnaeus, 1758) (Decapoda: Portunidae). Scientia Marina 57, 1-8.

Natunewicz, C.C., Epifanio, C.E., 2001. Spatial and temporal scales of patches of crab larvae in coastal waters. Marine Ecology-Progress Series 212, 217-222. 
Natunewicz, C.C., Epifanio, C.E., Garvine, R.W., 2001. Transport of crab larval patches in the Coastal Ocean. Marine Ecology-Progress Series 222, 143-154.

Nishimoto, M.M., Washburn, L., 2002. Patterns of coastal eddy circulation and abundance of pelagic juvenile fish in the Santa Barbara Channel, California, USA. Marine Ecology-Progress Series 241, 183-199.

O'Riordan, R.M., Myers, A.A., Cross, T.F., 1992. Brooding in the intertidal barnacles Chthamalus stellatus (Poli) and Chthamalus montagui Southward in south-western Ireland. Journal of Experimental Marine Biology and Ecology 164, 135-145.

O'Riordan, R.M., Myers, A.A., Cross, T.F., 1995. The reproductive cycles of Chthamalus stellatus (Poli) and C. montagui Southward in south-western Ireland. Journal of Experimental Marine Biology and Ecology 190, 17-38.

O’Riordan, R.M., Arenas, F., Arrontes, J., Castro, J.J., Cruz, T., Delany, J., Martinez, B., Fernandez, C., Hawkins, S.J., Mcgrath, D., Myers, A.A., Oliveros, J., Pannacciulli, F.G., Power, A.M., Relini, G., Rico, J.M., Silva, T., 2004. Spatial variation in the recruitment of the Intertidal Barnacles Chthamalus montagui Southward and Chthamalus stellatus (Poli) (Crustacea: Cirripedia) over an european scale. Journal of Experimental Marine Biology and Ecology 304, 243-264.

Okubo, A., 1994. The role of diffusion and related physical processes in dispersal and recruitment of marine populations. In: Sammarco, P.W., Heron, M.L. (Eds.), The Bio-Physics of Marine Larval Dispersal. American Geophysical Union, Washington, DC, pp. 5-32.

Olmi III, E.J., 1994. Vertical migration of blue crab Callinectes sapidus megalopae: implications for transport in estuaries. Marine Ecology Progress Series 113, 39-54.

Paula, J., Dray, T., Queiroga, H., 2001. Interaction of offshore and inshore processes controlling settlement of brachyuran megalopae in Saco mangrove creek, Inhaca Island (South Mozambique). Marine Ecology Progress Series 215, 251-260.

Peliz, A., Rosa, T., Santos, A.M.P., Pissarra, J., 2002. Fronts, jets, eddies and counterflows in the western iberia upwelling system. Journal of Marine Systems 35, 61-77.

Peliz, A., Marchesiello, P., Dubert, J., Roy, P., Almeida, M., Queiroga, H., 2006. A nested model of western Iberia shelf: validation and application to crab larvae dispersal. Journal of Marine Systems. doi:10.1016/j.jmarsys.2006.11.00.

Peterson, W., 1998. Life cycle strategies of copepods in coastal upwelling zones. Journal of Marine Systems 15, 313-326.

Petrone, C., Jancaitis, L.B., Jones, M.B., Natunewicz, C.C., Tilburg, C.E., Epifanio, C.E., 2005. Dynamics of larval patches: spatial distribution of fiddler crab larvae in delaware bay and adjacent waters. Marine Ecology-Progress Series 293, $177-190$.

Phillips, B.F., Pearce, A.F., 1997. Spiny lobster recruitment off Western Australia. Bulletin of Marine Science 61, 21-41.

Pineda, J., 1991. Predictable upwelling and the shoreward transport of planktonic larvae by internal tidal bores. Science 253, 548-551.

Pineda, J., 1994. Internal tidal bores in the nearshore: warm-water fronts, seaward gravity currents and the on-shore transport of neustonic larvae. Journal of Marine Research 52, 427-458.

Pineda, J., 1995. An internal tidal bore regime at nearshore stations along western USA - predictable upwelling within the lunar cycle. Continental Shelf Research 15, 1023-1041.

Pineda, J., 1999. Circulation and larval distribution in internal tidal bore warm fronts. Limnology and Oceanography $44,1400-1414$.

Pineda, J., 2000. Linking larval settlement to larval transport: assumptions, potentials and pitfalls. Oceanography of the Eastern Pacific 1, 84-105.

Poulin, E., Palma, A.T., Leiva, G., Hernandez, E., Martinez, P., Navarrete, S.A., Castilla, J.C., 2002a. Temporal and spatial variation in the distribution of epineustonic competent larvae of Concholepas concholepas along the central coast of Chile. Marine EcologyProgress Series 229, 95-104.

Poulin, E., Palma, A.T., Leiva, G., Narvaez, D., Pacheco, R., Navarrete, S.A., Castilla, J.C., 2002b. Avoiding offshore transport of competent larvae during upwelling events: the case of the gastropod Concholepas concholepas in central Chile. Limnology and Oceanography 47, 1248-1255.

Queiroga, H., 1996. Distribution and drift of the crab Carcinus maenas (L.) (Decapoda, Portunidae) larvae over the continental shelf off northern Portugal in April 1991. Journal of Plankton Research 18, 1981-2000.

Queiroga, H., 1998. Vertical migration and selective tidal stream transport in the megalopae of the crab Carcinus maenas. Hydrobiologia (375/376), 137-149.

Queiroga, H., Blanton, J.O., 2005. Interactions between behaviour and physical forcing in the control of horizontal transport of decapod crustaceans' larvae: an overview. Advances in Marine Biology 47, 107-214.

Queiroga, H., Costlow Jr., J.D., Moreira, M.H., 1994. Larval abundance patterns of Carcinus maenas (Decapoda, Brachyura) in Canal de Mira (Ria de Aveiro, Portugal). Marine Ecology Progress Series 111, 63-72.

Queiroga, H., Costlow Jr., J.D., Moreira, M.H., 1997. Vertical migration of the crab Carcinus maenas first zoea in an estuary: implications for tidal stream transport. Marine Ecology Progress Series 149, 121-132.

Queiroga, H., Almeida, M.J., Alpuim, T., Flores, A.A.V., Francisco, S., González-Gordillo, J.I., Miranda, A.I., Silva, I., Paula, J., 2006. Wind and tide control of megalopal supply to estuarine crab populations on the Portuguese west coast. Marine Ecology Progress Series 307, 21-36.

Range, P., Paula, A., 2001. Distribution, abundance and recruitment of Chthamalus (Crustacea : Cirripedia) populations along the central coast of Portugal. Journal of the Marine Biological Association of the United Kingdom 81, 461-468.

Rawlinson, K.A., Davenport, J., Barnes, D.K.A., 2005. Temporal variation in diversity and community structure of a semi-isolated neuston community. Proceedings of the Royal Irish Academy, B 105, 107-122.

Relvas, P., Barton, E.D., Dubert, J., Oliveira, P.B., Peliz, A., da Silva, J.C.B., Santos, A.M.P., 2007. Physical oceanography of the western Iberia ecosystem: Latest views and challenges. Progress in Oceanography 74 (2-3), 149-173.

Rimmer, D.W., Phillips, B.F., 1979. Diurnal migration and vertical distribution of phyllosoma larvae of the western rock lobster Panulirus cygnus. Marine Biology 54, 109-124. 
Roberts Jr., M.H., 1971. Larval development of Pagurus longicarpus Say reared in the laboratory. III. Behavioural responses to salinity discontinuities. Biological Bulletin 140, 489-501.

Roughgarden, J., Gaines, S., Possingham, H.P., 1988. Recruitment dynamics in complex life cycles. Science 241, $1460-1466$.

Roughgarden, J., Pennington, J.T., Stoner, D., Alexander, S., Miller, K., 1991. Collisions of upwelling fronts with the intertidal zone: the cause of recruitment pulses in barnacle populations of central California. Acta Oecologica 12, 35-51.

Santos, A.M.P., Peliz, A., Dubert, J., Oliveira, P.B., Angélico, M.M., Ré, P., 2004. Impact of a winter upwelling event on the distribution and transport of sardine eggs and larvae off western Iberia: a retention mechanism. Continental Shelf Research 24, 149-165.

Santos, A.M.P., Ré, P., dos Santos, A., Peliz, A., 2006. Vertical distribution of the European sardine (Sardina pilchardus) larvae and its implications for their survival. Journal of Plankton Research 28, 523-532.

Saunders, P.M., 1982. Circulation in the eastern north Atlantic. Journal of Marine Research 40, 641-657.

Serfling, S.A., Ford, R.F., 1975. Ecological studies of the puerulus larval stage of the California spiny lobster, Panulirus interruptus Fishery Bulletin 73, 360-377.

Shanks, A.L., 1983. Surface slicks associated with tidally forced internal waves may transport pelagic larvae of benthic invertebrates and fishes shoreward. Marine Ecology Progress Series 13, 311-315.

Shanks, A.L., 1985. Behavioral basis of internal-wave-induced shoreward transport of megalopae of the crab Pachygrapsus crassipes. Marine Ecology Progress Series 24, 289-295.

Shanks, A.L., 1986. Vertical migration and cross-shelf dispersal of larvalCancer spp. and Randallia ornata (Crustacea: Brachyura) off the coast of southern California. Marine Biology 92, 189-199.

Shanks, A.L., 1988. Further support for the hypothesis that internal waves can cause shoreward transport of larval invertebrates and fishes. Fisheries Bulletin 86, 703-714.

Shanks, A.L., 1995. Mechanisms of cross-shelf dispersal of larval invertebrates and fish. In: McEdward, L. (Ed.), Ecology of Marine Invertebrate Larvae. CRC Press, Boca Raton, pp. 323-367.

Shanks, A.L., 1998. Abundance of post-larval Callinectes sapidus, Penaeus, Uca, and Libinia collected at an outer coastal site and their cross-shelf transport. Marine Ecology - Progress Series 168, 57-69.

Shanks, A.L., Brink, L., 2005. Upwelling, downwelling, and cross-shelf transport of bivalve larvae: test of a hypothesis. Marine EcologyProgress Series 302, 1-12.

Shanks, A.L., Largier, J., Brink, L., 2000. Demonstration of the onshore transport of larval invertebrates by the shoreward movement of an upwelling front. Limnology and Oceanography 45, 230-236.

Sousa, E.B., Cruz, T., Castro, J.J., 2000. Distribution and abundance of co-occurring chthamalid barnacles Chthamalus montagui and Chthamalus stellatus (Crustacea, Cirripedia) on the southwest coast of Portugal. Hydrobiologia 440, 339-345.

Sponaugle, S., Lee, T., Kourafalou, V., Pinkard, D., 2005. Florida Current frontal eddies and the settlement of coral reef fishes. Limnology and Oceanography 50, 1033-1048.

Sulkin, S.D., Van Heukelem, W.F., Kelly, P., 1983. Behavioral basis of depth regulation in hatching and post-larval stages of the mud crab Eurypanopeus depressus. Marine Ecology Progress Series 11, 157-164.

Tankersley, R.A., McKelvey, L.M., Forward Jr., R.B., 1995. Responses of estuarine crab megalopae to pressure, salinity and light: Implications for flood-tide transport. Marine Biology 122, 391-400.

Tankersley, R.A., Welch, J.M., Forward Jr., R.B., 2002. Settlement times of blue crab (Callinectes sapidus) megalopae during flood-tide transport. Marine Ecology Progress Series 141, 863-875.

Tapia, F.J., Pineda, J., Ocampo-Torres, F.J., Fuchs, H.L., Parnell, P.E., Montero, P., Ramos, S., 2004. High-frequency observations of wind-forced onshore transport at a coastal site in Baja California. Continental Shelf Research 24, 1573-1585.

Turner, S.J., Grant, J., Pridmore, R.D., Hewitt, J.E., Wilkinson, M.R., Hume, T.M., Morrisey, D.J., 1997. Bedload and water-column transport and colonization processes by post-settlement benthic macrofauna: does infaunal density matter? Journal of Experimental Marine Biology and Ecology 216, 51-75.

Underwood, A.J., Fairweather, P.G., 1989. Supply-side ecology and benthic marine assemblages. Trends in Ecology and Evolution 4, 1621.

van Montfrans, J., Epifanio, C.E., Knott, D.M., Lipcius, R.N., Mense, D.J., Metcalf, K.S., Olmi III, E.J., Orth, R.J., Posey, M.H., Wenner, E.L., West, T.L., 1995. Settlement of blue crab postlarvae in western North Atlantic estuaries. Bulletin of Marine Science 57, 834-854.

Virnstein, R.W., 1977. Importance of predation by crabs and fishes on benthic infauna in Chesapeake Bay. Ecology 58, $1199-1217$.

Walker, G., 2004. Swimming speeds of the larval stages of the parasitic barnacle, Heterosaccus lunatus (Crustacea : Cirripedia : Rhizocephala). Journal of the Marine Biological Association of the United Kingdom 84, 737-742.

Welch, J.M., Forward Jr., R.B., 2001. Flood tide transport of blue crab, Callinectes sapidus, postlarvae: behavioral responses to salinity and turbulence. Marine Biology 139, 911-918.

Welch, J.M., Forward Jr., R.B., Howd, P.A., 1999. Behavioral responses of blue crab Callinectes sapidus larvae to turbulence: implications for selective tidal stream transport. Marine Ecology Progress Series 179, 135-143.

Wing, S.R., Botsford, L.W., Largier, J.L., Morgan, L.E., 1995a. Spatial structure of relaxation events and crab settlement in the northern California upwelling system. Marine Ecology Progress Series 128, 199-211.

Wing, S.R., Largier, J.L., Botsford, L.W., Quinn, J.F., 1995b. Settlement and transport of benthic invertebrates in an intermittent upwelling region. Limnology and Oceanography 40, 316-329.

Wooster, W.S., Bakun, A., McLain, D.R., 1976. The seasonal upwelling cycle along the eastern boundary of the North Atlantic. Journal of Marine Research 34, 131-141. 
Wootton, J.T., 1993. Indirect effects and habitat use in an intertidal community - interaction chains and interaction modifications. American Naturalist 141, 71-89.

Zeldis, J.R., Jillett, J.B., 1982. Aggregation of pelagic Munida-Gregaria (Fabricius) (Decapoda, Anomura) by coastal fronts and internal waves. Journal of Plankton Research 4, 839-857.

Zeng, C., Naylor, E., 1996a. Endogenous tidal rhythms of vertical migration in field collected zoea-1 larvae of the shore crab Carcinus maenas: implications for ebb tide offshore dispersal. Marine Ecology Progress Series 132, 71-82.

Zeng, C., Naylor, E., 1996b. Occurrence in coastal waters and endogenous tidal swimming rhythms of late megalopae of the shore crab Carcinus maenas: implications for onshore recruitment. Marine Ecology Progress Series 136, 69-79.

Zeng, C., Naylor, E., 1996c. Synchronization of endogenous tidal vertical migration rhythms in laboratory-hatched larvae of the crab Carcinus maenas. Journal of Experimental Marine Biology and Ecology 198, 269-289.

Zeng, C., Naylor, E., 1997. Rhythms of larval release in the shore crab Carcinu maenas (Decapoda: Brachyura). Journal of the Marine Biological Association of the United Kingdom 77, 451-461. 